\title{
Original Paper \\ Checklist of Angiosperms in the Restingas of Pará state, Brazil, with comments on floristic affinities and phytophysiognomies
}

\author{
Wanderson Luis da Silva e Silva ${ }^{1,4,10}$, Mônica Falcão da Silva ${ }^{1,5}$, Dário Dantas do Amaral ${ }^{2,6}$, \\ Maria de Nazaré Lima do Carmo ${ }^{2,7}$, Ely Simone Cajueiro Gurgel ${ }^{2,8}$ \& João Ubiratan Moreira dos Santos ${ }^{3,9}$
}

\begin{abstract}
Pará state has one of the longest coastal in Brazil. However, floristic surveys have been conducted in few regions and only one study has comprehensively evaluated the coastal flora of the state. The objective of this study was to create an updated and certified checklist of the angiosperms in the restingas of Pará. The list was made using literature, floristic and taxonomic revisions, herbaria specimens from HBRA, IAN, MFS and MG, and collections made between 2014 and 2018. Overall, 470 species, 279 genera and 92 families were recorded. Of this total, 11 species are new records for coastal Pará. The families with the greatest number of species are Fabaceae, Cyperaceae, Poaceae, Myrtaceae, Rubiaceae, Asteraceae, Apocynaceae, Polygalaceae, Convolvulaceae and Melastomataceae, which correspond to 52\% of the species. Cyperus, Eugenia, Rhynchospora, Eleocharis and Ipomoea are the most representative genera. For life forms, herbs and shrubs are predominant. Dune fields, restinga forest and herbaceous swamp are the phytophysiognomies with the greatest number of species. A comparison with restingas of northeastern Brazil showed that the flora surveyed is most similar to that of Maranhão, since many species of the Amazonian flora also occur in restingas in this state.
\end{abstract}

Key words: Amazon, coastal vegetation, floristic composition, littoral.

\section{Resumo}

O Pará possui um dos maiores litorais brasileiros. Entretanto, levantamentos florísticos foram realizados em poucas regiões e apenas um estudo avaliou de forma abrangente a flora costeira do estado. O presente estudo teve como objetivo fornecer um checklist atualizado e certificado das Angiospermas das restingas do Pará. A lista foi elaborada através de literatura de referência, revisões florístico-taxonômicas de grupos com ocorrência nas restingas paraenses, material dos herbários HBRA, IAN, MFS e MG e coletas entre 2014 e 2018. Foram listadas 470 táxons, 279 gêneros e 92 famílias. Deste total, 11 táxons são apresentados como novas ocorrências para o litoral paraense. As famílias com maior número de espécies foram Fabaceae, Cyperaceae, Poaceae, Myrtaceae, Rubiaceae, Asteraceae, Apocynaceae, Polygalaceae, Convolvulaceae e Melastomataceae, correspondendo a 52\% dos táxons. Cyperus, Eugenia, Rhynchospora, Eleocharis e Ipomoea foram os gêneros mais representativos. Quanto às formas de vida, ervas e arbustos foram predominantes. Campo de dunas, Floresta de restinga e Brejo herbáceo foram as fitofisionomias com maior número de táxons. A comparação da flora encontrada, com a de restingas do Nordeste brasileiro, mostrou maior afinidade com a do Maranhão, com muitas espécies provenientes da flora amazônica colonizando as restingas desse estado. Palavras-chave: Amazônia, vegetação costeira, composição florística, litoral.

\footnotetext{
${ }^{1}$ Museu Paraense Emilio Goeldi, Prog. Pós-graduação em Biodiversidade e Biotecnologia do Norte-Bionorte, São Braz, Belém, PA, Brazil.

${ }^{2}$ Museu Paraense Emílio Goeldi, Coord. Botânica, Terra Firme, Belém, PA, Brazil.

${ }^{3}$ Universidade Federal Rural da Amazônia, Inst. Ciências Agrárias, Terra Firme, Belém, PA, Brazil.

${ }^{4}$ ORCID: < https://orcid.org/0000-0002-2796-8797>.

${ }^{5}$ ORCID: < https://orcid.org/0000-0002-5028-9274>.

${ }^{6}$ ORCID: $<$ https://orcid.org/0000-0002-3546-5719>.

${ }^{7}$ ORCID: < https://orcid.org/0000-0002-8418-1464>.

${ }^{8}$ ORCID: <https://orcid.org/0000-0002-9488-7532>.

${ }^{9}$ ORCID: < https://orcid.org/0000-0001-9850-0334>.

${ }^{10}$ Author for correspondence: wl.silvasilva@gmail.com
} 


\section{Introduction}

Approximately $70 \%$ of coastal Brazil is occupied by dune and restinga formations, which are discontinuous due to characteristics of the soil and topography (Rizzini 1979; Silva et al. 2010). In Amazonia, this pioneer ecosystem occurs in northeastern Pará and is formed by plant communities on sandy Quaternary plains under marine influence, with small elevations and distinct phytophysiognomies in the direction of the ocean to the continent (Bastos 1996; Silva et al. 2010).

According to Flora of Brazil 2020 (BFG 2015), the largest gap in the knowledge about the vegetation of the country is still in Amazonia. This includes restingas, which have been studied more in the Northeast (Almeida Jr. et al. 2007, 2017; Zickel et al. 2007; Silva et al. 2008; Santos-Filho et al. 2011, 2015; Oliveira et al. 2014) and Southeast (Araújo et al. 2009; Souza et al. 2016) coastal regions of Brazil.

Brazilian restingas have been destroyed due to urban expansion and illegal extractivism (Scarano et al. 2004), and studies of this ecosystem have advanced at a slower rate compared to the increase in this degradation (Scherer et al. 2005). In Pará, the main threats are the illegal extraction of material for civil construction, tourism and fire (Silva et al. 2010; Amaral et al. 2016).

Since the work of Pires (1973), which proposed a classification for Amazonian plant formations, a little over 60 studies have been conducted in restingas in Pará, including abstracts, scientific articles, theses and dissertations. Some of these works focus on species aspects of the vegetation: floristics/phytosociology (Bastos 1996; Santos et al. 2003; Silva et al. 2010; Quaresma \& Jardim 2015); relationships of plant communities and environmental factors (Jardim et al. 2016; Silva et al. 2018); and taxonomic groups (Vicente et al. 1999; Rocha 2000; Rocha et al. 2001a,b; Rocha \& Bastos 2004; Rosário et al. 2005; Margalho et al. 2009; Sousa et al. 2009; Barbosa et al. 2013; Mesquita et al.2013; Abreu et al. 2014; Lima et al. 2014; Falcão-da-Silva et al. 2015a, b; Schneider et al. 2017). In addition, Bastos et al. (2003) covers botanical and medicinal use aspects and a book by Bastos et al. (2014) is about flowers and fruits that are part of the beauty of these environments.

The diversity of angiosperms in Amazonian restingas was evaluated by Amaral et al. (2008). This publication lists 365 species for coastal Pará and Amapá and is based on determinations on herbarium collections; however, it does not cite specimens. After a decade, this is still the only comprehensive work about the coastal flora of Pará. Considering the possible increase in herbarium collections and new determinations of species, as a result of a growth in knowledge about the flora of Brazil in recent years (BFG 2018), this work provides a certified checklist of the angiosperms in the restingas of Pará.

\section{Material and Methods}

\section{Study area}

The areas of restinga in Pará are concentrated in the northeastern part of the state (approximately $598 \mathrm{~km}$ ), including the municipalities of Bragança and Augusto Corrêa (Bragantina region) and Curuçá, Maracanã, Marapanim, Salinópolis, São Caetano de Odivelas and São João de Pirabas (Salgado region) (Fig. 1). In addition to the restingas on the mainland, in an eastern part of Marajó Island (Salvaterra and Soure municipalities) there are areas of this ecosystem associated with areas transitioning to Amazonian savanna (Amaral 2016).

Restinga vegetation in Pará is generally formed of different complex physiognomies on a sandy plain, including areas with herbaceous halophiles or rhizomatous psammophiles, herbaceous swamps, dune fields, open formations with bushes and restinga forest, as described by Bastos (1996). The soil is sandy, poor in clay and organic material, and has a low capacity to retain water and nutrients (Bastos et al. 2003). The climate is the Am type based on the Köpen classification (Alvares et al. 2013). The annual rainfall is $2,500-3,100 \mathrm{~mm}$, the average annual temperature is $27{ }^{\circ} \mathrm{C}$ and the relative humidity of the air is around $80-85 \%$ (Sudam 1984; Martorano et al. 1993; Alvares et al. 2013).

\section{Data sampling and analysis}

The list of species that occur in the restingas of Pará was obtained from two main sources: (i) reference literature about the restinga flora of coastal Pará (Santos \& Rosário 1988; Bastos 1988; Amaral et al. 2008, 2016) and floristic-taxonomic revisions of groups that are known to occur in restingas of the state; and (ii) specimens deposited in herbaria that concentrate on records of the state (HBRA, IAN, MFS and MG). Acronyms according to Thiers (continuously updated).

Expeditions were also made between 2014 and 2018. While collecting, the random walk method was adopted, as described by Filgueiras 
et al. (1994), with the goal of sampling the majority of the restinga phytophysiognomies; fertile material was collected and processed based on the methods used in plant taxonomy (Bridson \& Forman 1998).

The samples collected, and undetermined herbarium specimens, were identified based on taxonomic revisions, regional floras, comparison with collections determined by specialist and literature about each family. The collections were deposited in MG at the Museu Paraense Emílio Goeldi.

The classification of families follows APG IV (2016), except for Turneraceae that is treated as independent of Passifloraceae. The information about life forms and phytophysiognomies (habitats) is based on field observations, specimen labels and the literature. The classification for the phytophysiognomies follows Bastos (1996) and the classification for the life forms follows IBGE (2012), except species of climbers, which is based on the definitions of liana and herbaceous vine by Queiroz (2009). Only one confirmed voucher specimen per taxon is cited (Tab. S1, available on supplementary material <https://doi.org/10.6084/ m9.figshare.13681750.v1 >). Data about endemism in Brazil and authors of species are based on the Flora of Brazil 2020 and Tropicos websites, as well as literature about each family.

\section{Results}

Based on the data collected, approximately 5,000 specimens of angiosperms from restingas of Pará were verified, which represented 470 species belonging to 279 genera and 92 families (Tab. S1, available on supplementary material $<$ https://doi.org/10.6084/m9.figshare.13681750. v1>; Fig. 2). The ten most representative families were Fabaceae (67 spp.), Cyperaceae (52 spp.), Poaceae (32 spp.), Myrtaceae (22 spp.), Rubiaceae (18 spp.), Asteraceae (12 spp.), Apocynaceae and Polygalaceae (11 spp. each) and Convolvulaceae and Melastomataceae (10 spp. each), corresponding to $52 \%$ of the total number of species (Fig. 3). Thirty-three families $(35.8 \%$ of the total) were represented by only one species.

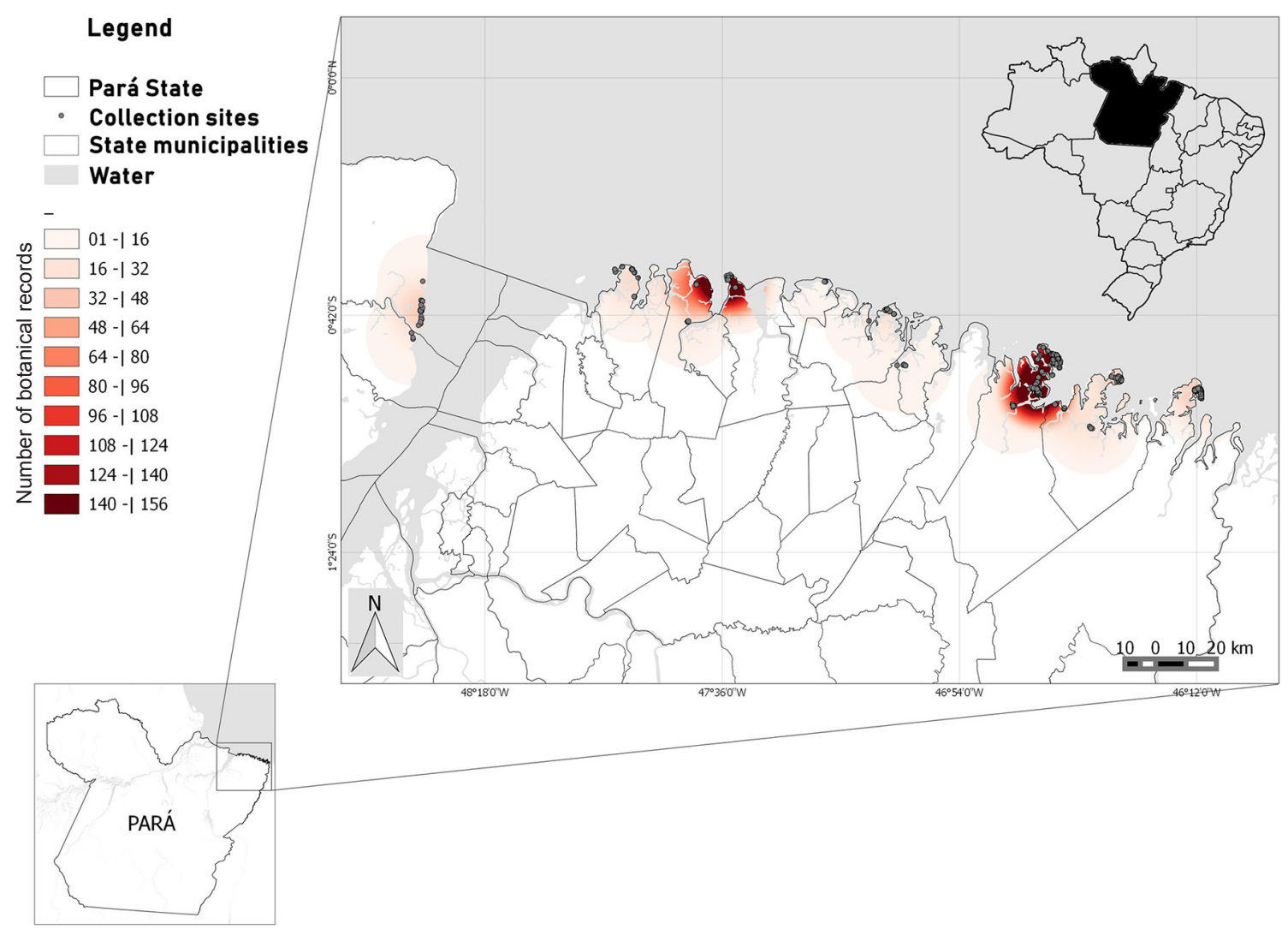

Figure 1 - Distribution of the angiosperm collections from restingas of Pará state, Brazil. 

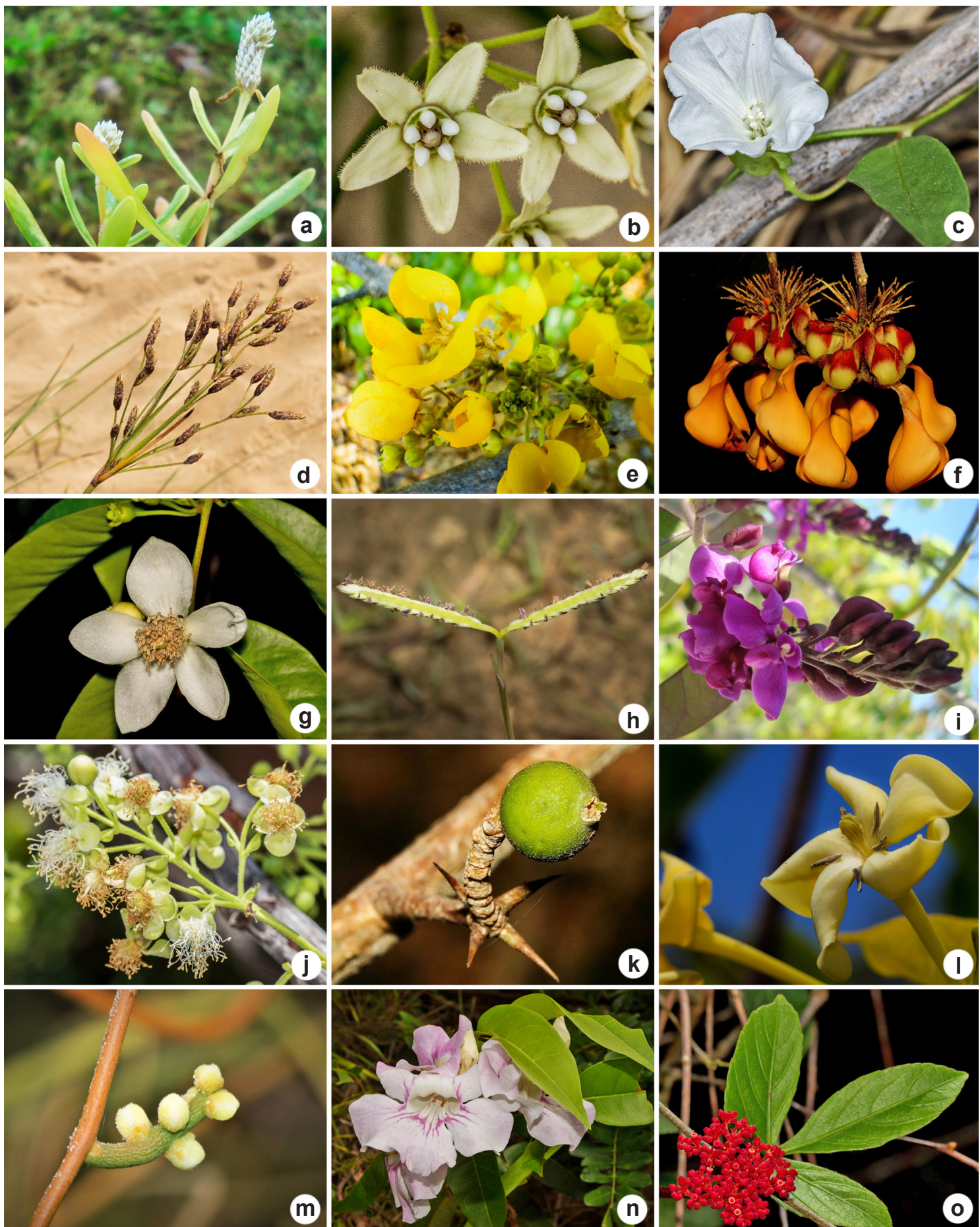

Figure 2 - a-o. Some species recorded from restingas of Pará state, Brazil - a. Blutaparon vermiculare (Amaranthaceae); b. Funastrum clausum (Apocynaceae); c. Aniseia martinicensis (Convolvulaceae); d. Fimbristylis spadicea (Cyperaceae); e. Chamaecrista bahiae (Fabaceae); f. Erythrina fusca (Fabaceae); g. Calycolpus goetheanus (Rubiaceae); h. Paspalum vaginatum (Poaceae); i. Securidaca diversifolia (Polygalaceae); j. Curatella americana (Dilleniaceae); k. Randia armata (Rubiaceae); 1. Tocoyena brasiliensis (Rubiaceae); m. Cassytha filiformis (Lauraceae); n. Bignonia aequinoctialis (Bignoniaceae); o. Cissus erosa (Vitaceae). 


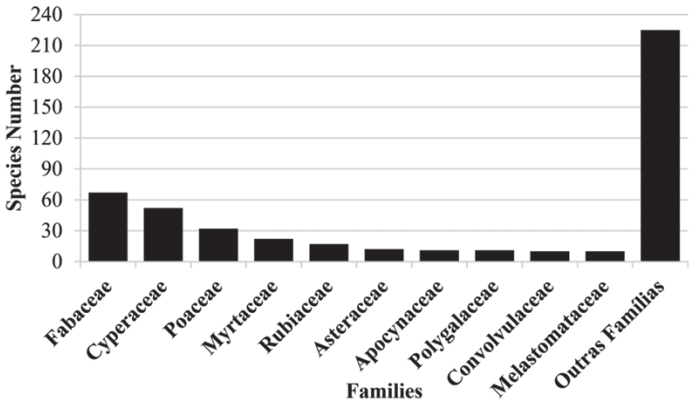

Figure 3 - Most species-rich families in restingas of Pará state, Brazil.

The genera most diverse in number of species were the following: Cyperus L. (Cyperaceae) (17 spp.), Eugenia L. (Myrtaceae) (11 spp.), Rhynchospora Vahl (Cyperaceae) (10 spp.), Eleocharis R.Br. (Cyperaceae) (8 spp.), Ipomoea L. (Convolvulaceae) (8 spp.), Myrcia DC. (Myrtaceae) (7 spp.), Paspalum L. (Poaceae) (6 spp.), Scleria P.J. Bergius (Cyperaceae) (6 spp.), Syngonanthus Ruhland (Eriocaulaceae) (6 spp.) and Chamaecrista Moench (5 spp.) (Fig. 4).

Herbs are the dominant plant life form in the restingas of Pará (199 spp., 42.3\% of the total), followed by shrubs and subshrubs (86 spp., 18.3\%), trees (51 spp., 10.7\%), lianas (38 spp., 8.1\%), herbaceous vines (16 spp., 3.4\%) and palms (3 spp., $0.6 \%$ ). Seventy-seven species were recorded as having more than one life form, mainly those that can be trees or scandent shrubs.

Among the families with mainly species of shrubs and trees, Fabaceae (23 spp.), Myrtaceae (21 spp.), Rubiaceae (14 spp.) and Sapotaceae (7 spp.) are notable for being the most representative in number of species, mainly in the restinga forest phytophysiognomy. Cyperaceae (52 spp.), Poaceae (32 spp.) and Fabaceae (19 spp.) are the most representative families of terrestrial herbs, which is due to the high occurrence of individuals of these families in open dune formations and flooded areas, especially those of Cyperaceae that dominate these swampy environments.

The group of climbers is mostly represented by individuals of Fabaceae, which are mainly herbaceous vines; however, Apocynaceae, Bignoniaceae, Convolvulaceae and Dilleniaceae have numerous species with a lianescent life form.

There is a considerable difference in the richness recorded for the different phytophysiognomies. Dune fields and restinga forest are the richest, with up to $39.4 \%$ of the angiosperm flora in the restingas of Pará. For dune fields, 100 exclusive species in 85 genera and 44 families were recorded. The richest families in this environment are Poaceae (13 spp.), Cyperaceae (8 spp.) and Fabaceae ( 8 spp.), which mainly comprise biological entities with an herbaceous life form. A total of 59 species $(59 \%$ of the flora in this environment) are herbs, notably representatives of Paspalum (Poaceae) (5 spp.) and Cyperus (Cyperaceae) (3 spp.).

For the restinga forest, 85 exclusive species in 67 genera and 35 families were recorded. Fabaceae (15 spp.), Myrtaceae (10 spp.) and Rubiaceae (9 spp.) are the most representative in this phytophysiognomy, forming a large part of the arboreal and shrub elements that include 78 biological entities $(91.7 \%$ of the flora in this environment), mainly Myrtaceae, such as Eugenia L. (5 spp.) and Myrcia DC. (3 spp.), and Casearia Jacq. (Salicaceae), Ficus L. (Moraceae) and Hirtella (Chrysobalanaceae), each with three species.

For the herbaceous swamp, 47 exclusive species in 31 genera and 16 families were recorded. Cyperaceae (13 spp.), Poaceae (5 spp.) and Xyridaceae (4 spp.) are the most representative families in this wet environment,

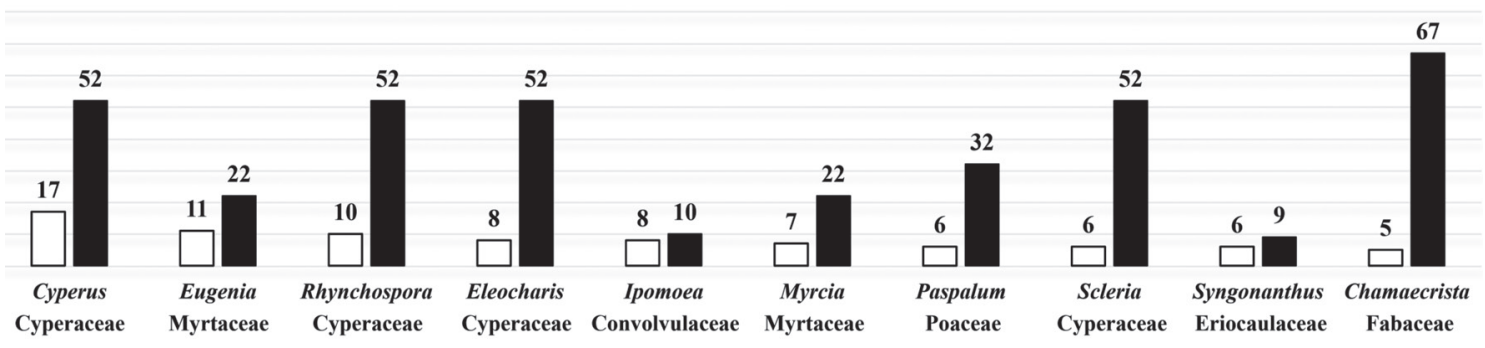

Figure 4 - Richest genera in restingas of Pará state, Brazil. (hollow area = number of species per genus; filled area $=$ total number of species per family). 
mainly Rhynchospora Vahl (7 spp.) and Xyris Gronov. ex L. (4 spp.).

The flora of the restingas in Pará includes 57 species endemic to Brazil (Tab. S1, available on supplementary material <https://doi.org/10.6084/ m9.figshare.13681750.v1>); however, there are no species exclusive to Amazonian restingas. Fabaceae (8 spp.), Rubiaceae (5 spp.), Myrtaceae and Polygalaceae (4 spp. each), and Asteraceae and Cyperaceae ( $3 \mathrm{spp}$. each) are the families with the greatest number of species endemic to Brazil recorded for the coast of Pará.

Even with a small increase in sampling effort, together with advances in taxonomic knowledge, it is not uncommon for checklists and broader floristic studies to record new occurrences for many plant groups.

The present survey of restingas in Pará found 11 new records for the state, including Blutaparon portulacoides (A.St.-Hil.) Mears (Amaranthaceae), Blutaparon vermiculare (L.) Mears (Amaranthaceae), Anthurium sinuatum Benth. ex Schott (Araceae), Cereus jamacaru DC. (Cactaceae), Cyperus macrostachyos Lamarck (Cyperaceae), Drosera capillaris Poir. (Droseraceae), Cuphea flava Spreng. (Lythraceae), Passiflora amethystina J.C.Mikan (Passifloraceae), Asemeia rhodoptera (Mart. ex A.W.Benn.) J.F.B.Pastore \& J.R.Abbott (Polygalaceae), Guettarda angelica Mart. ex Müll.Arg. (Rubiaceae) and Smilax campestris Griseb. (Smilacaceae).

\section{Discussion}

In a survey conducted by Amaral et al. (2008), 365 species were recorded for the restingas of coastal Pará and Amapá, which corresponds to only $77.8 \%$ of the species listed here. In addition, these authors also included five species of ferns and lycophytes in their checklist.

The analysis of the flora of restingas of Pará indicates relatively low richness in relation to the coastal extension of the state, which is similar to the richness recorded in studies of restingas in states of the Northeast Region of Brazil when taking into account the differences in the length of the coastline of each state and the collection effort and inclusion criteria of the flora (vascular flora or only angiosperms). For these states, the following have been cataloged: 401 spp. for Maranhão (640 $\mathrm{km}$ of coast) (Almeida Jr. et al. 2017); $934 \mathrm{spp}$. for Bahia (140 km) (Gomes \& Guedes 2014); 391 spp. for Ceará (573 km) (Santos-Filho et al. 2011); 363 spp. for Piauí (66 km) (Santos-Filho et al. 2015);
477 spp. for Pernambuco $(187 \mathrm{~km})$ (Zickel et al. 2007); and $831 \mathrm{spp}$. for Sergipe (168 km) (Oliveira et al. 2014).

The difference in the richness between the restingas in Pará and those of the Northeast Region of Brazil also indicates a heterogeneous distribution of the records of the flora in these environments in the state, which is probably because the large coastal extension has resulted in collecting in the most accessible points compared to more expensive expeditions to less accessible areas. This can be seen when mapping the existing collections from restingas in the state, since a large part of the records are from the municipalities of Bragança, Marapanim and Macaranã, of which the latter two are geographically close (Fig. 1).

Based on expeditions conducted for this study, 11 species were confirmed that had never been cited for restingas of Pará (Tab. S1, available on supplementary material $<$ https:// doi.org/10.6084/m9. figshare.13681750.v1>). However, new studies are still important to confirm the true floristic richness of coastal Pará, since they will fill knowledge gaps and directly affect the development of research about restinga species in different areas, resulting in a better understanding of the ecological dynamics of these environments.

The richest families recorded in this study are also the most relevant in lists of the restinga flora of the Northeast Region of Brazil, in which Fabaceae, Cyperaceae, Poaceae, Myrtaceae and Rubiaceae are always cited as having the greatest number of species (Zickel et al. 2007; Santos-Filho et al. 2011, 2015; Gomes \& Guedes 2014; Oliveira et al. 2014, 2015; Almeida Jr. et al. 2017). Gentry (1988) cites Fabaceae as the dominant family in different Amazonian formations.

When comparing restingas of Pará to those of the Northeast Region, it is important to consider the variety and diversity of physiognomic typologies in each area. This factor directly influences not only species richness but also structural and taxonomic composition, resulting in differences in the composition of the richest families. For example, few floristic studies of restingas in the Northeast and Southeast regions of Brazil mention Polygalaceae among the 10 families with the greatest number of species (Souza et al. 2016; Almeida Jr. et al. 2017; Castelo \& Braga 2017), indicating a peculiar difference exhibited by Amazonian restingas.

The richest family cited in restingas of the Northeast Region of Brazil is Fabaceae, which 
is possibly because many representatives of the family exhibit great plasticity to different niches and easily grow under extreme nutritional conditions, mainly due to symbiosis with nitrogen fixing bacteria. In the present study, this family was recorded for all phytophysiognomies, from areas of rhizomatous psammophiles, herbaceous swamps and dune fields to restinga forest, where it is the group with the greatest number of species. Recently, Silva et al. (2019) confirmed 16 new occurrences of this family for restingas in Pará.

Cyperaceae and Poaceae are also dominant in restingas of the Northeast Region of Brazil, notably in the states of Ceará (Santos-Filho et al. 2011) and Sergipe (Oliveira et al. 2014) that have a similar richness compared to coastal Pará; for all three states, they are listed as some of the richest families in herbaceous swamps and dune fields. This is probably because representatives of these families easily reproduce and are wind dispersed in these environments, guaranteeing establishment in open formations with high luminosity (Almeida Jr. et al. 2009; Cantarelli et al. 2012).

Among the species endemic to Brazil that are cited for restingas of Pará, the following are notable: Swartzia brachyrachis var. snethlageae (Ducke) Ducke (Fabaceae), which is restricted to Pará (in formations of restinga, campinarana, igapó forest and terra firme forest) and Maranhão, although Almeida Jr. et al. (2017) does not cite restinga for this state; and Eleocharis bahiensis D.A.Simpson (Cyperaceae), which has a disjunct distribution in Pará and Bahia and is always associated with restinga vegetation, aquatic environments or rocky outgroups (Giulietti et al. 2009; Nunes et al. 2021). Giulietti et al. (2009) mentions that the latter species is rare and, at that moment, only known from the state of Bahia.

In the species listed as new records confirmed for the flora of Pará (Tab. S1, available on supplementary material < https://doi.org/10.6084/ m9.figshare.13681750.v1>), Cuphea flava Spreng. (Lythraceae) is notable for being endemic to Brazil and cited only for areas of restinga in the Northeast and Southeast regions (Cavalcanti et al. 2021). In restingas in Pará, this species has been recorded many times by specialists of the family. Asemeia rhodoptera (Mart. ex A.W.Benn.) J.F.B.Pastore \& J.R.Abbott (Polygalaceae) is endemic to Brazil and cited as restricted to phytophysiognomies of the Cerrado, such as campo limpo and campo rupestre (Aguiar et al. 2008; Mota \& Pastore 2021). It has only two confirmed records for restingas in Pará, which reinforces the need for floristic studies in poorly collected restingas of the state.

Four species of Ouratea Aubl. (Ochnaceae) were recorded for restingas of Pará. Two species are endemic to Brazil, Ouratea cassinifolia (A.DC.) Engl., which is only known from Pará and Maranhão (Flora do Brasil 2020), and Ouratea racemiformis Ule, which occurs in the states of Amazonas, Amapá, Pará and Maranhão (Amaral et al. 2008; Almeida Jr. et al. 2017; Flora do Brasil 2020). All confirmed records of both species are from costal or riparian areas.

Blutaparon Raf. (Amaranthaceae) is represented by only two species in Brazil (Senna 2021), Blutaparon portulacoides (A.St.-Hil.) Mears and Blutaparon vermiculare (L.) Mears, which are cited as exclusive to areas of restinga. The confirmation of the occurrence of these species for coastal Pará indicates that, although not endemic, the species are present the coastal Rio de Janeiro (Castelo \& Braga 2017) to Maranhão (Serra et al. 2016; Almeida Jr. et al. 2017; Lima \& Almeida Jr. 2018).

The occurrence of the same species in different areas of restinga along coastal Brazil might indicate that, to a greater or lesser degree, the vegetation of this environment plays a role as an ecological corridor among different phytogeographic domains. Amaral et al. (2015) noted the coexistence of species with different origins in an area of restinga in Pará. Most of the arboreal elements in this area originate from Amazonian vegetation formations and the shrubs, to an extent, are widely distributed species in Brazil. Serra et al. (2016) noted the occurrence of typical Amazonian species in coastal areas of Maranhão and Lima \& Almeida Jr. (2018) observed high floristic similarity among restingas of Pará and Maranhão, which indicates that restingas of coastal Maranhão are colonized by species of the Amazonian biome.

Recently, Amaral et al. (2016) documented the first records of Curatella americana L. (Dilleniaceae) for coastal areas of Amazonia. In studies of continental restingas this species had never been mentioned. In the state, it was known only from restingas on Marajó Island, where there are many populations adjacent to areas of cerrado and it is a dominant species, indicting the possible influence of this vegetation on the colonization process of restinga areas in that region. This was observed for Polygalaceae. Of the eleven species 
in the family recorded for restingas of Pará, seven are abundant in areas of cerrado on Marajó Island (Costa 2012).

According to Flora do Brazil 2020, restingas of Pará are composed mostly of species that occur in both anthropic areas and many Amazonian habitats (terra firme forest and white sand vegetation), as well as other domains, such as the Atlantic Forest, Cerrado and Caatinga in the Northeast and Southeast regions of the country, demonstrating the importance of adjacent floras to the composition of restinga vegetation.

As indicated by Amaral et al. (2008), dune fields, herbaceous swamp and restinga forest are the physiognomic formations with the greatest richness in restingas of Pará. The first two mainly comprise herbaceous vegetation, since open formations predominate in restingas in the state. This allows areas to be colonized by a dynamic herbaceous vegetation cover, which is possibly regulated seasonally by rainfall and changes in the groundwater level. However, the forest formation is dominated by arboreal elements, less dynamic and predominantly regulated by edaphic conditions. Amaral et al. (2008), Almeida Jr. et al. (2009) and Santos-Filho et al. (2013) noted that these environmental characteristics directly influence the proportion of dominance of life forms in the different restinga physiognomies.

From an ecological perspective, the absence of endemism contrasts with the important diversity found in Amazonian restinga. Species that colonize geologically recent environments, such as restinga, make morphological, physiological and ecological adjustments to the severe climatic and nutritional conditions of these areas. This shows the value of genetic richness, which is still not taken into account in biological conservation strategies in Brazil (Scarano 2006). Thus, it is vital that the areas of restinga in Pará remain a priority for the conservation of biodiversity in the state.

\section{Conclusions}

We recorded the occurrence of 470 species of angiosperms in areas of restinga in coastal Pará, mainly species of Fabaceae, Cyperaceae, Poaceae, Myrtaceae and Rubiaceae. Dune fields and restinga forest had the greatest richness among the phytophysiognomies. This work is a survey that updated what is known about the restinga flora of Pará, based on a study from 10 years ago, and the 11 new occurrences reported are important results. Further, significant areas of this vegetation are still poorly explored. It was found that in the last decade there was an intensification of collecting in areas already widely visited, except for coastal restinga of Marajó Island that was surveyed more recently, resulting in a better understanding of this environment. In general, we hope this work contributes to advances in research and effective management and conservation strategies related to restingas, which are important environments in Amazonia.

\section{Acknowledgements}

The authors thank the following: CAPES (Coordenação de Aperfeiçoamento de Pessoal de Nível Superior), for the financial support and for awarding the postgraduate fellowships to the first and second authors (project PRO AMAZÔNIA 3268/2013); the curators at the herbaria visited (MG, IAN and MFS); and the Grupo de Estudos de Mamíferos Aquáticos da Amazônia (GEMAM), of the Bicho D'Água project, for the field support.

\section{References}

Abreu JLL, Santos JUM, Pereira ASS \& Barbosa CVO (2014) Estudo taxonômico de Ouratea Aubl. (Ochnaceae) ocorrentes na restinga da vila José Bonifácio, Bragança-PA. Enciclopédia Biosfera 10: 2259-2267.

Aguiar ACA, Marques MCM \& Yamamoto K (2008) Taxonomia das espécies de Polygala L. subgênero Hebeclada (Chodat) Blake (Polygalaceae) ocorrentes no Brasil. Revista Brasileira de Biociências 6: 81109.

Almeida Jr. EB, Pimentel RMM \& Zickel CS (2007) Flora e formas de vida em uma área de restinga no litoral norte de Pernambuco, Brasil. Revista de Geografia 24: 19-34.

Almeida Jr. EB, Olivo MA, Araújo EL \& Zickel CS (2009) Caracterização da vegetação de restinga da RPPN de Maracaípe, Pernambuco, com base na fisionomia, flora, nutrientes do solo e lençol freático. Acta Botanica Brasilica 23: 36-48.

Almeida Jr. EB, Silva ANF, Lima GP, Amorim IFF, Serra FCV \& Correia BEF (2017) Checklist of the flora of the restingas of Maranhão state, Northeast, Brazil. Indian Journal Of Applied Research 7: 603-612.

Alvares CA, Stape JL, Sentelhas PC, Gonçalves JLM \& Sparovek G (2013) Köppen's climate classification map for Brazil. Meteorologische Zeitschrift 22: 711-728.

Amaral DD, Costa-Neto SV, Jardim MA, Santos JUM \& Bastos MN (2016) Curatella americana L. (Dilleniaceae): primeira ocorrência nas restingas do litoral da Amazônia. Revista Brasileira de Biociências 14: 257-262. 
Amaral DD, Jardim MAG, Costa-Neto SV \& Bastos MNC (2015) Síndromes de dispersão de propágulos e a influência da floresta amazônica na composição de espécies lenhosas de uma restinga no litoral norte brasileiro. Biota Amazônia 5: 28-37.

Amaral DD, Prost TM, Bastos MNC, Costa-Neto SV \& Santos JUM (2008) Restingas do Litoral Amazônico, estados do Amapá e Pará, Brasil. Boletim do Museu Paraense Emílio Goeldi 3: 35-67.

APG (2016) An update of the Angiosperm Phylogeny Group classification for the orders and families of flowering plants: APG IV. Botanical Journal of the Linnean Society 181: 1-20.

Araújo DSD, Sá CFC, Fontella-Pereira J, Garcia DS, Ferreira MV \& Paixão RJ (2009) Área de proteção ambiental de Massambaba, Rio de Janeiro: caracterização fitofisionômica e florística. Rodriguésia 60: 67-96.

Barbosa CVO, Bastos MNC, Sousa JS \& Cruz APO (2013) Estudo taxonômico de Sapindaceae do litoral paraense. Rodriguésia 64: 807-815.

Bastos MNC (1988) Levantamento florístico em restinga arenosa litorânea na Ilha Maiandeua-Pará. Boletim do Museu Paraense Emilio Goeldi Série Botânica 4: 159-173.

Bastos MNC (1996) Caracterização das formações vegetais da Restinga da Princesa, Ilha do Algodoal - Pará. Brasil. Tese de Doutorado. Universidade Federal do Pará e Museu Paraense Emílio Goeldi, Belém. 249p.

Bastos MNC, Torres DCC \& Santos JUM (2003) Vegetação de Restinga: aspectos botânicos e uso medicinal. Museu Paraense Emílio Goeldi, Belém. $23 \mathrm{p}$.

Bastos MNC, Santos JUM, Cardoso ALR \& Gurgel ESC (2014) Flores e frutos das restingas do estado do Pará. Universidade Federal rural da Amazônia, Belém. 246p.

BFG (2015) Growing knowledge: an overview of Seed Plant diversity in Brazil. Rodriguésia 66: 1085-1113.

BFG (2018) Brazilian Flora 2020: Innovation and collaboration to meet Target 1 of the Global Strategy for Plant Conservation (GSPC). Rodriguésia 69: 1513-1527.

Bridson D \& Forman L (1998) International Herbarium Handbook. $3^{\text {rd }}$ ed. Royal Botanic Gardens, Kew. $334 \mathrm{p}$.

Cantarelli JRR, Almeida Jr. EB, Santos-Filho FS \& Zickel CS (2012) Tipos fitofisionômicos e florística da restinga da APA de Guadalupe, Pernambuco, Brasil. Insula 41: 95-117.

Castelo AJ \& Braga JMA (2017) Checklist of sand dune vegetation on the tropical southeastern Brazil coast. Check List 13: 2058.

Cavalcanti TB, Graham SAT, Facco MG \& Brauner LM (2021) Cuphea. In: Flora do Brasil 2020 em construção. Jardim Botânico do Rio de Janeiro. Available at $<\mathrm{http}$ ://floradobrasil.jbrj.gov.br/reflora/
floradobrasil/FB8746>. Access on 11 January 2021. Costa CS (2012) A família Polygalaceae na Ilha do Marajó - Pará, Brasil. Dissertação de Mestrado. Universidade Federal Rural da Amazônia / Museu Paraense Emílio Goeldi, Belém. 144p.

Falcão-Da-Silva M, Bastos MNC \& Gurgel ESC (2015a) Dalbergieae (Leguminosae-Papilionoideae) nas restingas amazônicas. Pesquisas Botânicas 68: 83-10.

Falcão-Da-Silva M, Bastos MNC \& Gurgel ESC (2015b) Phaseoleae (Leguminosae - Papilionoideae) nas restingas do estado do Pará, Brasil. Biota Amazônia 5: 14-22.

Filgueiras TS, Brochado AL, Nogueira PE \& Guala GF (1994) Caminhamento - um método expedito para levantamentos florísticos qualitativos. Cadernos de Geociências 2: 39-43.

Flora do Brasil 2020 em construção. Instituto de Pesquisas Jardim Botânico do Rio de Janeiro. Available at <http://floradobrasil.jbrj.gov.br/>. Access on 11 January 2021.

Gentry AH (1988) Changes in plant community diversity and floristic composition on environmental and geographical gradients. Annals of Missouri Botanical Garden 75: 1-34.

Giulietti AM, Rapini A, Andrade MJG, Queiroz LP \& Silva JMC (2009) Plantas raras do Brasil. Conservação Internacional, Belo Horizonte. 496p.

Gomes FS \& Guedes MLS (2014) Flora vascular e formas de vida das formações de restinga do litoral norte da Bahia, Brasil. Acta Biológica Catarinense 1: $22-43$.

IBGE (2012) Manual Técnico da Vegetação Brasileira. Série Manuais Técnicos em Geociências 1. $2^{\text {nd }}$ ed. IBGE, Rio de Janeiro. 271p.

Jardim DG, Jardim MAG, Quaresma AC \& Costa-Neto SV (2016) Fatores edáficos e as variações florísticas da regeneração natural em duas formações florestais. Biota Amazônia 6: 66-72.

Lima GP \& Almeida Jr. EB (2018) Diversidade e smilaridade florística de uma restinga ecotonal no Maranhão, Nordeste do Brasil. Interciência 43: 275-282.

Lima LFG, Santos JUM, Rosário AS \& Baumgratz JFA (2014) Melastomataceae em formações costeiras de restingas no Pará, Brasil. Acta Amazônica 44: 45-58.

Margalho LF, Rocha AES \& Secco RS (2009) Rubiaceae Juss. da restinga da APA de Algodoal/Maiandeua, Maracanã, Pará, Brasil. Boletim do Museu Paraense Emílio Goeldi. Ciências Naturais 4: 303-339.

Martorano LG, Pereira LC, César EGM, Pereira ICB, Santos ECR \& Santos FAC (1993) Estudos climáticos do estado do Pará, classificação climática (Köppen) e deficiência hídrica (Thornthwhite, Mather). Superintendência de Desenvolvimento da Amazônia, Empresa Brasileira de Pesquisas Agropecuárias, Serviço Nacional de Levantamento e Conservação de Solos, Belém. 53p. 
Mesquita AS, Rocha AES \& Santos JUM (2013) Polygalaceae nas restingas do estado do Pará, Brasil. Revista Brasileira de Biociências 11: 76-87.

Mota MAM \& Pastore JFB (2021) Asemeia. In: Flora do Brasil 2020 em construção. Jardim Botânico do Rio de Janeiro. Available at $<$ http://floradobrasil. jbrj.gov.br/reflora/floradobrasil/FB127263>. Access on 11 January 2021.

Nunes CS, Maciel-Silva JF, Trevisan R \& Gil ASB (2021) Eleocharis. In: Flora do Brasil 2020 em construção. Jardim Botânico do Rio de Janeiro. Available at $<$ http://floradobrasil.jbrj.gov.br/reflora/ floradobrasil/FB25412>. Access on 11 January 2021.

Oliveira EVS, Lima JF, Silva TC \& Landim MF (2014) Checklist of the flora of the Restingas of Sergipe state, Northeast Brazil. Check List 10: 529-549.

Oliveira EVS, Ferreira-Sobrinho ES \& Landim MF (2015) Flora from the Restingas of Santa Isabel Biological Reserve, northern coast of Sergipe state, Brazil. Check List 11: 1779.

Pires JM (1973) Tipos de vegetação da Amazônia. O Museu Goeldi no ano do Sesquicentenário. Publicação Avulsa do Museu Paraense Emílio Goeldi 20: 179-202.

Quaresma AC \& Jardim MAG (2015) Formações florestais de restinga e relações ecológicas com lianas. Revista Árvore 39: 255-261.

Queiroz LP (2009) Leguminosas da Caatinga. Universidade Estadual de Feira de Santana: Royal Botanic Gardens, Kew. Associação Plantas do Nordeste, Feira de Santana. 467p.

Rizzini CT (1979) Tratado de fitogeografia do Brasil. Vol. 2. Aspectos ecológicos. Hucitec. Edusp, São Paulo. 123p.

Rocha AES (2000) Poaceae na restinga da praia da Princesa, APA de Algodoal/Maiandeua, Maracanã - Pará, Brasil. Dissertação de Mestrado. Faculdade de Ciências Agrárias, Belém. 114p.

Rocha AES, Bastos MNC \& Santos JUM (2001a) O gênero Paspalum L. (Gramineae/Poaceae) na restinga da Praia da Princesa, APA de Algodoal/ Maiandeua, Maracanã, Pará, Brasil. Boletim do Museu Paraense Emilio Goeldi série Botânica 17: 187-207.

Rocha AES, Bastos MNC \& Secco RS (2001b) O gênero Panicum L. (Gramineae/Poaceae) na restinga da Praia da Princesa, APA de Algodoal/Maiandeua, Maracanã, Pará. Boletim do Museu Paraense Emilio Goeldi série Botânica 17: 297-314.

Rocha AES \& Bastos MNC (2004) Flora fanerogâmica das restingas do Pará. APA de Algodoal-Maiandeua. II - Eriocaulaceae P. Beauv. ex Desv. Hoehnea 31: 103-111.

Rosário AS, Secco RS, Amaral DD, Santos JUM \& Bastos MNC (2005) Flórula fanerogâmica das restingas do estado do Pará. Ilhas de Algodoal e Maiandeua - 2. Myrtaceae A.L. de Jussieu. Boletim do Museu
Paraense Emilio Goeldi Série Botânica 1: 31-48.

Santos JUM \& Rosário CS (1988) Levantamento da vegetação fixadora de dunas de Algodoal - PA. Boletim do Museu Paraense Emilio Goeldi, Série Botânica 4: 133-151.

Santos JUM, Amaral DD, Gorayeb IS, Bastos MNC, Secco RS, Costa-Neto SV \& Costa DCT (2003) Vegetação da área de proteção ambiental JabotitiuaJatium, município de Viseu, Pará, Brasil. Acta Amazônica 33: 431-444.

Santos-Filho FS, Almeida Jr. EB, Bezerra LFM, Lima LF \& Zickel CS (2011) Magnoliophyta, restinga vegetation, state of Ceará, Brazil. Check List 7 : 478-485.

Santos-Filho FS, Almeida Jr. EB \& Zickel CS (2013) Do edaphic aspects alter vegetation structures in the Brazilian restinga? Acta Botanica Brasilica 27: 613-623.

Santos-Filho FS, Almeida Jr. EB, Lima LF \& Soares CJRS (2015) Checklist of the flora of the restingas of Piauí state, Northeast Brazil. Check List 11: 1598-1608.

Scarano FR, Cirne P, Nascimento MT, Sampaio MC, Villela DM \& Wendt T (2004) Ecologia Vegetal: integrando ecossistema, comunidade, populações e organismos. In: Rocha CFD, Esteves FA \& Scarano FR (ed.) Pesquisas de longa duração na Restinga de Jurubatiba: Ecologia, História Natural e Conservação. RiMa Editora, São Carlos, São Paulo. Pp. 77-97.

Scarano FR (2006) Prioridades para conservação: a linha tênue que separa teorias e dogmas. In: Rocha CFD, Bergallo HG, Alves MAS \& Van Sluys M (ed.) Biologia da conservação: essências. Editora RiMa, São Carlos, São Paulo. Pp. 23-39.

Scherer A, Maraschi-Silva F \& Baptista LRM (2005) Florística e estrutura do componente arbóreo de matas de Restinga arenosa no Parque Estadual de Itapuã, RS, Brasil. Acta Botanica Brasilica 19: 715-726.

Schneider LJC, Bastos MNC, Costa-Neto SV \& Gil ASB (2017) Sinopse do gênero Rhynchospora (Cyperaceae) nas restingas do estado do Pará, Brasil. Rodriguésia 68: 653-670.

Senna LR (2021) Amaranthaceae. In: Flora do Brasil 2020 em construção. Jardim Botânico do Rio de Janeiro. Available at $<\mathrm{http}$ ://floradobrasil.jbrj.gov. br/reflora/floradobrasil/FB15410>. Access on 11 January 2021.

Serra FCV, Lima PB \& Almeida Jr. EB (2016) Species richness in resting vegetation on the eastern Maranhão state, Northeastern Brazil. Acta Amazonica 46: 271-280.

Silva RM, Mehlig U, Santos JUM \& Menezes MPM (2010) The coastal restinga vegetation of Pará, Brazilian Amazon: a synthesis. Brazilian Journal of Botany 33: 563-573.

Silva RM, Reis ACA \& Mehlig U (2018) Diversity and 
dominance patterns in Amazon coast dune forest island tree communities. Plant Ecology 219: 343357.

Silva SSL, Zickel CS \& Cestaro LA (2008) Flora vascular e perfil fisionômico de uma restinga no litoral sul de Pernambuco. Acta Botanica Brasilica 22: 1123-1135.

Silva WLS, Falcão-Da-Silva M, Gurgel ESC, Secco RS, Bastos MNC \& Santos JUM (2019) Diversidade e chaves de identificação das Leguminosae ocorrentes nas restingas do estado do Pará, Brasil. Boletim do Museu Paraense Emílio Goeldi. Ciências Naturais 14: 11-30.

Sousa JS, Bastos MNC \& RochaAES (2009) Mimosoideae (Leguminosae) do litoral paraense. Acta Amazonica 39: 799-812.

Souza WO, Machado JO, Tognella MMP \& AlvesAraújo A (2016) Checklist de Angiospermas do Parque Estadual de Itaúnas, Espírito Santo, Brasil. Rodriguésia 67: 571-581.
Sudam (1984) Atlas Climatológico da Amazônia Brasileira. Projeto de Hidrologia e Climatologia da Amazônia. Publicação no 39. Superintendência de Desenvolvimento da Amazônia, Belém. 125p.

Thiers B [continuously updated] Index Herbariorum: a global directory of public herbaria and associated staff. New York Botanical Garden's Virtual Herbarium. Available at <http://sweetgum.nybg.org/ science/ih/>. Access on 15 April 2019.

Vicente ACA, Macedo EG, Santos JUM, Potiguara RCV \& Bastos MNC (1999) Flórula fanerogâmica das restingas do estado do Pará. Ilha de Algodoal. I - Família Turneraceae A.P. de Candolle. Boletim do Museu Paraense Emilio Goeldi Série Botânica 15: 173-198.

Zickel CS, Almeida Jr. EB, Medeiros DPW, Lima PB, Souza TMS \& Lima AB (2007) Magnoliophyta species of restinga, state of Pernambuco, Brazil. Check List 3: 224-241. 